\title{
Future Euroson Schools
}
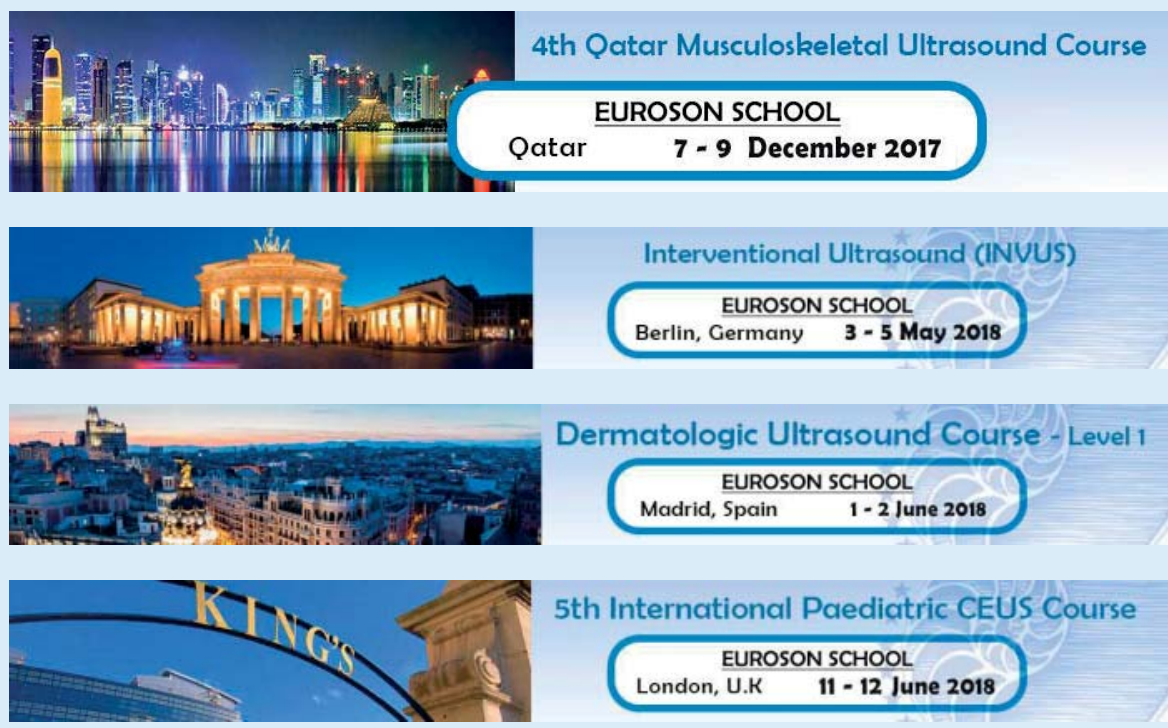

5th International Paediatric CEUS Course EUROSON SCHOOL

London, U.K $\quad 11-12$ June 2018
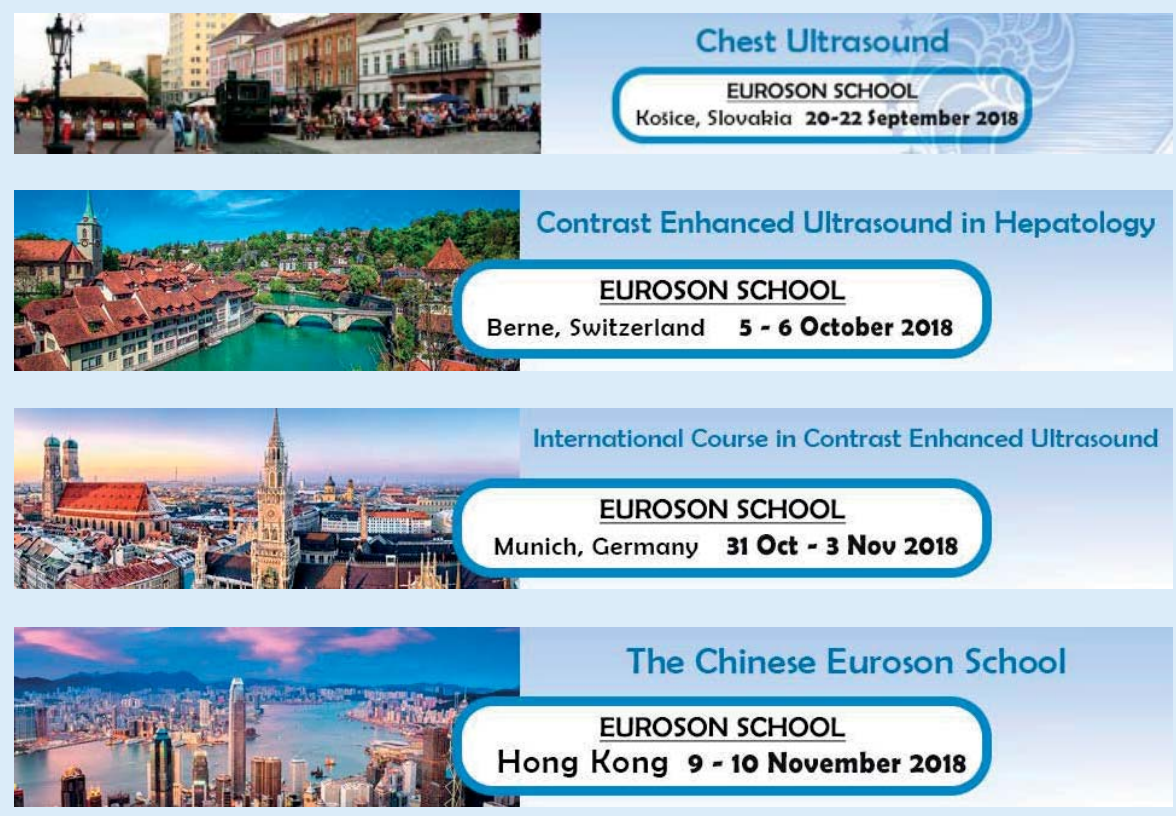